AJIE - Asian Journal of Innovation and Entrepreneurship

(e-ISSN: 2477-0574 ; p-ISSN: 2477-3824)

Vol. 01, No. 03, September 2016

\title{
PEMBERDAYAAN MASYARAKAT DI DESA SIDOREJO KABUPATEN PURWOREJO MELALUI PENGUATAN KELEMBAGAAN BERBASIS PENGEMBANGAN POTENSI LOKAL
}

\author{
Nur Feriyanto 1 \\ ${ }^{1}$ Program Studi Ekonomi Pembangunan, Universitas Islam Indonesia \\ e-mail: nur.feriyanto@uii.ac.id
}

\begin{abstract}
With the enactment of Law No. 6 of 2014 on the village then became a tremendous opportunity for every village in Indonesia to be able to develop all their potential independently according to the needs of each in order to realize the public welfare. Law number 6 th 2014 Article 4 is to encourage initiative, movement, and the participation of the village community to the development potential and assets for the welfare of the village together; as well as improve the economy of the village community and overcome the gap of national development. But this time there is very little village that is able to develop its potential. It is due to this village for more positioned as the object of development so it relied on the help of the central government. Low creativity of human resources in the village as a result of the development system is centralized in the past resulted in a lot of potential left to rot is not developed to the source of the prosperity of society. In an effort to manage the existing potential, the necessary institutional strengthening through the establishment of institutional capacity building in a professional, efficient, effective and responsible so as to improve the economy of the community and solve the problems of poverty that has been happening.
\end{abstract}

Keyword: Act Village, and institutional strengthening

\begin{abstract}
ABSTRAK
Dengan diberlakukannya Undang-undang nomor 6 tahun 2014 tentang Desa maka menjadi peluang yang sangat besar bagi setiap desa yang ada di Indonesia untuk bisa mengembangkan setiap potensi yang dimilikinya secara mandiri sesuai kebutuhan masing-masing dalam rangka mewujudkan kesejahteraan masyarakat. UU nomor 6 th 2014 pasal 4 tersebut bertujuan mendorong prakarsa, gerakan, dan partisipasi masyarakat Desa untuk pengembangan potensi dan Aset Desa guna kesejahteraan bersama; serta memajukan perekonomian masyarakat Desa serta mengatasi kesenjangan pembangunan nasional. Namun saat ini masih sangat sedikit desa yang mampu mengembangkan potensinya. Hal ini disebabkan selama ini desa lebih banyak diposisikan sebagai obyek pembangunan sehingga sangat menggantungkan diri pada bantuan pemerintah pusat. Rendahnya kreatifitas sumber daya manusia di desa sebagai akibat dari sistem pembangunan yang bersifat sentralistik pada masa lalu mengakibatkan banyak potensi dibiarkan terbengkalai tidak dikembangkan untuk sumber kemakmuran masyarakat. Dalam upaya mengelola potensi yang ada tersebut, maka diperlukan penguatan kelembagaan melalui peningkatan kapasitas dalam terwujudnya kelembagaan yang profesional, efisien dan efektif serta bertanggung jawab sehingga maтри memajukan perekonomian masyarakat dan mengatasi permasalahan kemiskinan yang selama ini terjadi.
\end{abstract}

Kata Kunci: Undang-undang Desa, dan Penguatan kelembagaan 


\section{LATAR BELAKANG}

Dengan diberlakukannya Undangundang nomor 6 tahun 2014 tentang Desa maka menjadi peluang yang sangat besar bagi setiap desa yang ada di Indonesia untuk bisa mengembangkan setiap potensi yang dimilikinya secara mandiri sesuai kebutuhan masing-masing dalam rangka mewujudkan kesejahteraan masyarakat. UU nomor 6 th 2014 pasal 4 tersebut bertujuan mendorong prakarsa, gerakan, dan partisipasi masyarakat Desa untuk pengembangan potensi dan Aset Desa guna kesejahteraan bersama; serta memajukan perekonomian masyarakat Desa serta mengatasi kesenjangan pembangunan nasional.

Namun saat ini masih sangat sedikit desa yang mampu mengembangkan potensinya. Hal ini disebabkan selama ini desa lebih banyak diposisikan sebagai obyek pembangunan sehingga sangat menggantungkan diri pada bantuan pemerintah pusat. Rendahnya kreatifitas sumber daya manusia di desa sebagai akibat dari sistem pembangunan yang bersifat sentralistik pada masa lalu mengakibatkan banyak potensi dibiarkan terbengkalai tidak dikembangkan untuk sumber kemakmuran masyarakat.

Pembangunan desa hakekatnya merupakan basis dari pembangunan nasional, karena apabila setiap desa telah mampu melaksanakan pembangunan secara mandiri maka kemakmuran masyarakat akan mudah terwujud dan secara nasional akan meningkatkan indek kemakmuran masyarakat Indonesia. Untuk bisa mewujudkan semua ini maka pemerintahan desa bersama-sama dengan segenap lembaga dan tokoh masyarakat perlu mengenali potensi apa saja yang ada baik fisik maupun non-fisik dan memahami bagaimana strategi dan cara mengembangkan potensi tersebut agar bisa dimanfaatkan sebesar-besarnya untuk kemakmuran masyarakat.

Dalam pengembangan potensi desa harus diseuaikan dengan permasalahan kehidupan atau kebutuhan masyarakat agar hasilnya benar-benar bisa dirasakan untuk meningkatkan kesejahteraan secara luas sesuai tujuan yang telah disepakati bersama. Dalam upaya mengelola potensi yang ada tersebut, maka diperlukan penguatan kelembagaan melalui peningkatan kapasitas dalam terwujudnya kelembagaan yang profesional, efisien dan efektif serta bertanggung jawab sehingga mampu memajukan perekonomian masyarakat dan mengatasi permasalahan kemiskinan yang selama ini terjadi. Desa sidorejo merupakan wilayah desa di Kabupaten Purworejo yang masuk dalam kategori kemiskinan sedang, faktor ini dilihat dari tingkat ekonomi warga, pekerjaan, tingkat pendidikan, rumah tinggal dan kesehatan. Menurut data dari pemerintahan desa, kemiskinan di wilayah Desa Sidorejo berjumlah 363 jiwa penduduk yang tersebar di 5 pedukuhan yaitu di Pedukuhan Bokongan berjumlah 53 jiwa, Sorogenen berjumlah 24 jiwa, Jurangjero berjumlah 97 jiwa, dan Jambean berjumlah 189 jiwa (sumber desa Sidorejo 2014).

Ketidak berdayaan dan kemampuan lembaga desa dalam mengelola potensi desa yang ada, menjadikan pengentasan kemiskinan di Desa Sidorejo mengalami stagnasi, hal tersebut dikarenakan lembaga desa tidak memiliki peran dan tanggung jawabnya dalam pengentasan kemiskinan berbasis pengembangan potensi lokal yang ada.. Permasalahan permasalahan tersebut akibat dari: 


\begin{tabular}{|c|c|c|}
\hline No & Aspek & Permasalahan \\
\hline 1. & $\begin{array}{l}\text { Tidak adanya perencanaan } \\
\text { dalammenyongsong UU } \\
\text { Desa no } 6 \text { tahun } 2014\end{array}$ & $\begin{array}{l}\text { 1. Kemampuan SDM dalam memamahami UU } \\
\text { Desa no } 6 \text { tahun } 2014 \\
\text { 2. Kemampuan SDM dalam membuat perencaaan } \\
\text { pengembangan desa terbatas } \\
\text { 3. Tidak adanya perencanaan pengembangan } \\
\text { jangka pendek dan panjang } \\
\text { 4. SDM dalam menyusun perencanaan berdasarkan } \\
\text { kebutuhan } \\
\text { 5. Ketidaktahuan SDM dalam membuat } \\
\text { perencanaan yang baik }\end{array}$ \\
\hline 2. & $\begin{array}{l}\text { Tidak ada pemetaan dan } \\
\text { profil wilayah }\end{array}$ & $\begin{array}{l}\text { 1. SDM tidak memiliki kemampuan memotret } \\
\text { potensi wilayah } \\
\text { 2. SDM tidak memiliki kemampuan dalam } \\
\text { memetakan wilayah } \\
\text { 3. SDM tidak memiliki kemampuan dalam } \\
\text { menyusun profil desa }\end{array}$ \\
\hline 3. & $\begin{array}{l}\text { Keterbatasan kemampuan } \\
\text { lembaga dalam mengelola } \\
\text { potensi desa }\end{array}$ & $\begin{array}{l}\text { 1. Tidak adanya pendataan potensi desa } \\
\text { 2. Tidak adanya tanggung jawab SDM dalam } \\
\text { pengembangan potensi desa } \\
\text { 3. Kemampuan SDM dalam mengembangkan } \\
\text { potensi yang ada terbatas }\end{array}$ \\
\hline
\end{tabular}

\section{METODE PELAKSANAAN}

Dalam mengatasi permasalahan tersebut di atas maka metode yang digunakan supaya program dapat berkelanjutan adalah dengan metode pendampingan, pelatihan, implementasi,dan evaluasi dengan tahapan kegiatan sebagai berikut:

1) Persiapan dan Pembekalan

a) Rekruitmen mahasiswa

b) Sosialisasi ke masayarakat penguna program KKN -PPM

c) Persiapan mahasiswa dan pembekalan KKN- PPM

d) Penejunan mahasiswa kelokasi KKN PPM

2) Pelaksanaan Kegiatan
a) Pendampingan
peningkatan kapasitas tata kelola pemerintahan desa
b) Pendampingan administrasi desa

c) Melaksanakan pemetaan potensi dan profil wilayah berbasis swadaya masyarakat

d) Studi wilayah di desa lain yang berhasil dalam pengembangan potensi lokal

e) Pendampingan pendataan potensi lokal

\section{HASIL DAN PEMBAHASAN \\ Realisasi Kegiatan}

Program kegiatan KKN UII dilaksanakan melalui beberapa tahapan, yaitu tahap persiapan, tahap pelaksanaan serta tahap evaluasi dan pelaporan.

\section{Tahapan Persiapan}

Untuk pelaksanaan KKN selalu diawali dengan tahapan persiapan, yaitu mempersiapkan calon mahasiswa KKN dan mempersiapkan pembekalan bagi. 


\section{Seleksi Mahasiswa}

Tahap persiapan awal adalah menyeleksi mahasiswa pendaftar KKN melalui seleksi administrasi serta test kesiapan pengetahuan dan kecakapan. Seleksi ini dimaksudkan untuk mendapatkan mahasiswa yang dibutuhkan sesuai dengan tema program KKN PPM. Tujuan seleksi ini dilakukan untuk menemukan mahasiswa yang sesuai harapan program. Seleksi dilakukan pada waktu 21 s/d 23 Juni 2016.

\section{Pembekalan Mahasiswa}

Pelaksanaan pembekalan ini bertujuan untuk mendekatkan pemahaman mahasiswa terhadap kebutuhan tema program yang akan dilaksanakan oleh mahasiswa. Tahapan pembekalan mahasiswa KKN PPM berdasarkan kesesuaikan kebutuhan tema program, yaitu pembekalan materi ilmu terapan sesuai disiplin ilmu masing-masing mahasiswa. Mulai materi umum, materi administrasi, materi kemasyarakatan, materi kewirausahaan, materi kecakapan khusus dan materi manajemen dan program KKN PPM. Untuk pembekalan menggunakan materi standar 5 bidang, namun isi materi disesuaikan "tema yang diangkat dalam program suatu wilayah". Pelaksanaannya dilakukan pada 23 s/d 24 Juli 2016, meliputi:

1. Bidang " Pengembangan Industri Ekonomi Kreatif Berbasis Wirausaha dan Etika Global.

2. Bidang "Pengembangan Virtual Environment (VE) untuk pendidikan, pemerintahan dan bisnis desa"

3. Bidang "Pengembangan Kawasan Pedesaan untuk peningkatan Kesejahteraan Masyarakat".

4. Bidang "Pengembangan Lingkungan dan Permikuman yang Cerdas, Lestari dan Berbasis Potensi wilayah"

5. Bidang "Kemasyarakatan dan Kewilayahan"

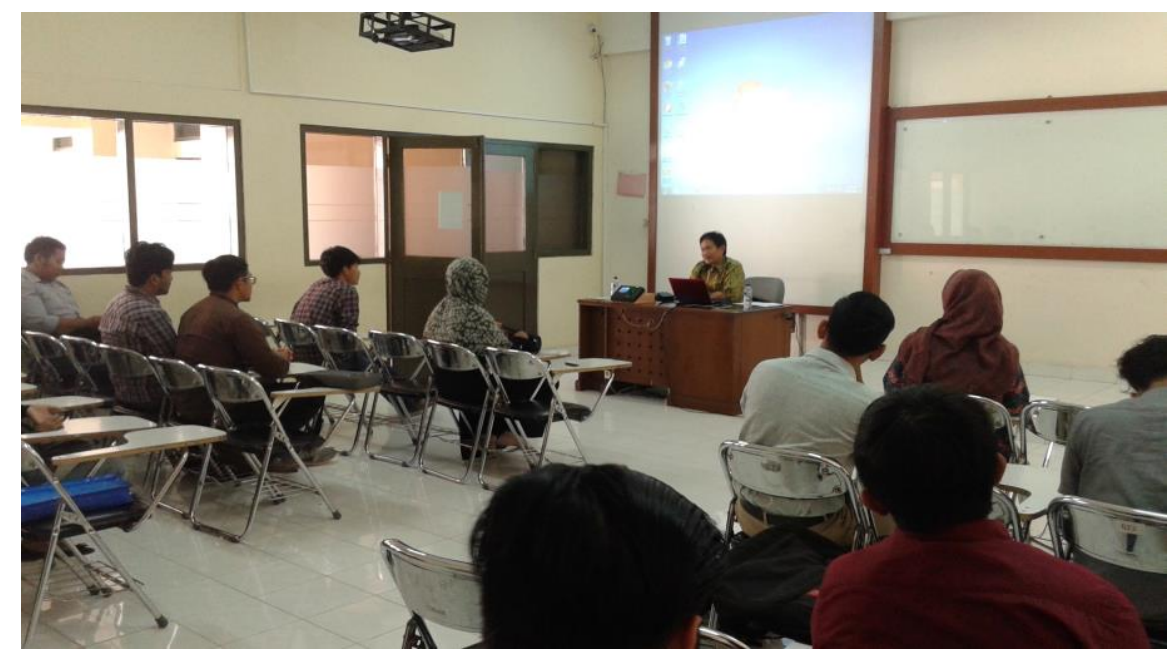

Gambar 1. Kegiatan Pembekalan dan Kewilayahan

Pengarahan, Pelepasan dan Penerjunan Mahasiswa

Pelaksanaan pengarahan, pelepasan dan penerjunan mahasiswa ini dimaksudkan untuk pembekalan umum oleh pejabat Rektorat untuk memberikan motivasi, dukungan dan arahan selama pelaksanaan $\mathrm{KKN}$, diharapkan mahasiswa 
mampu menjaga diri, bersosialisasi dan bertugas menyelesaikan kegiatan $\mathrm{KKN}$

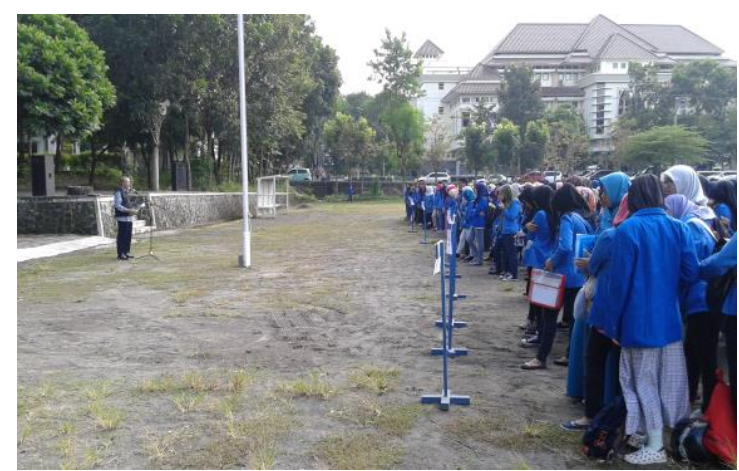

dengan baik dan benar.

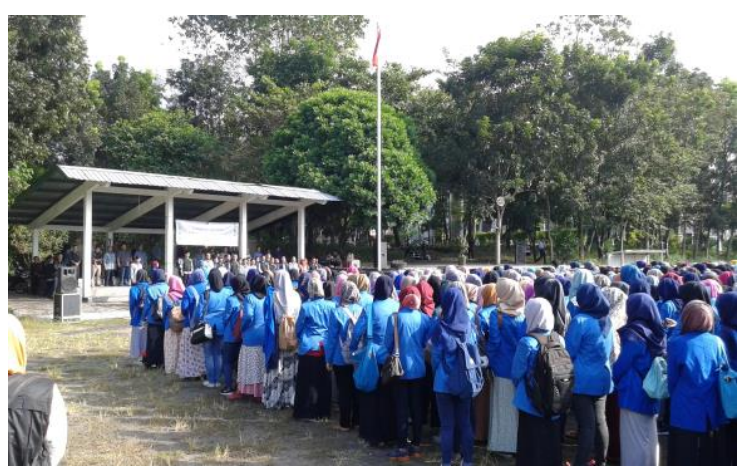

Gambar 2. Kegiatan Pengarahan dan Pelepasan Mahasiswa KKN-PPM

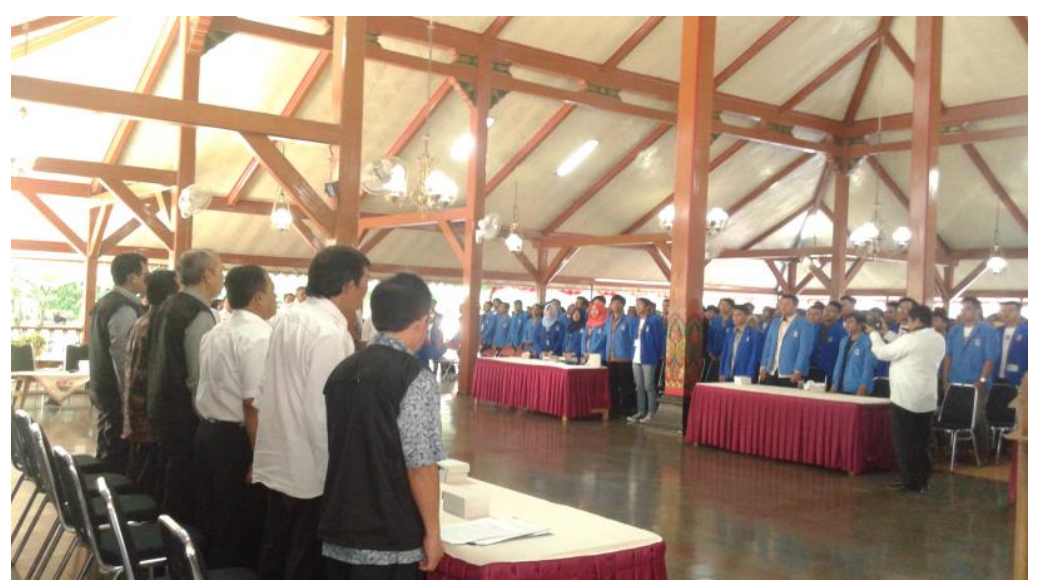

Gambar 3. Penerimaan Mahasiswa KKN-PPM di Kabupaten Purworejo

Tahapan Realisasi Program Koordinasi dengan Pemerintah Kabupaten dan Masyarakat

Untuk pelaksanaan KKN-PPM telah dilakukan koordinasi dan sosialisasi program-program kepada pemerintah daerah dan masyarakat sasaran, untuk penyusunan kesepakatan bersama dalam pelaksanaan program yang akan dilaksanakan.

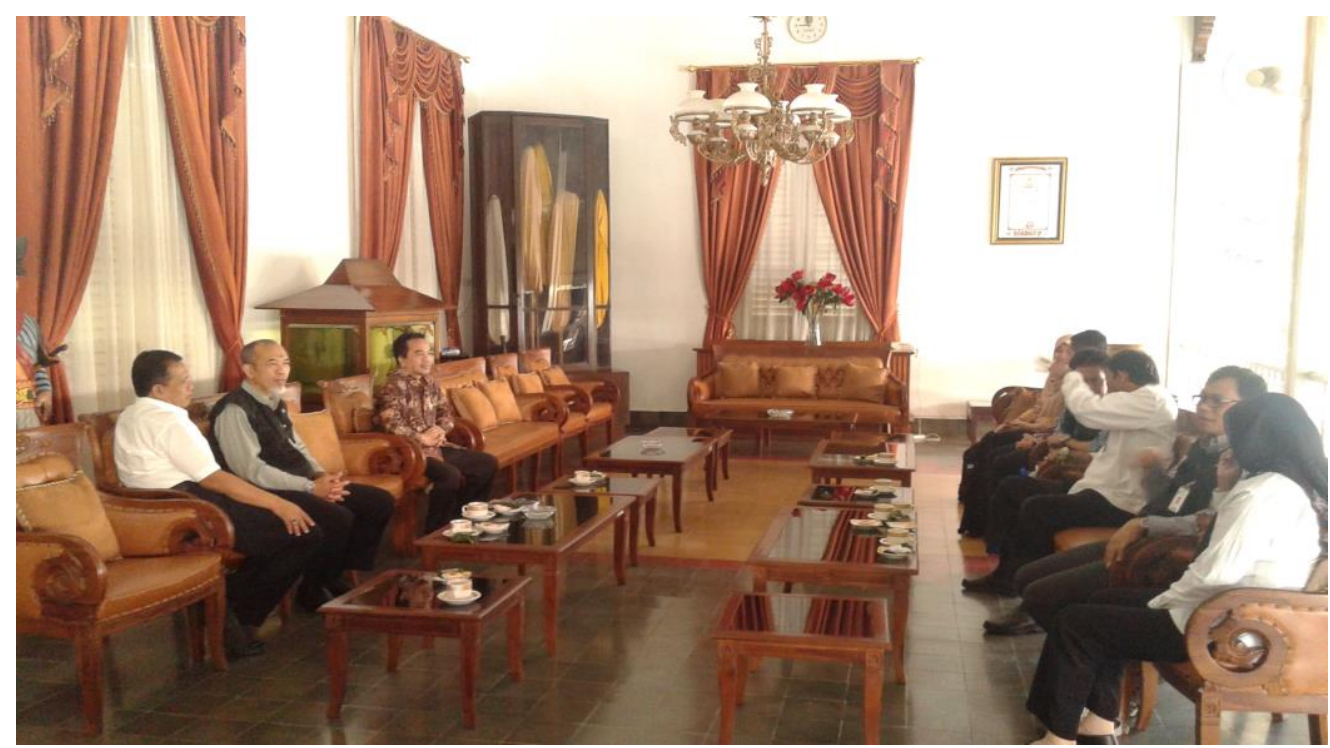

Gambar 4. Koordinasi Pelaksanaan KKN-PPM dengan Pemerintah Kabupaten Purworejo 

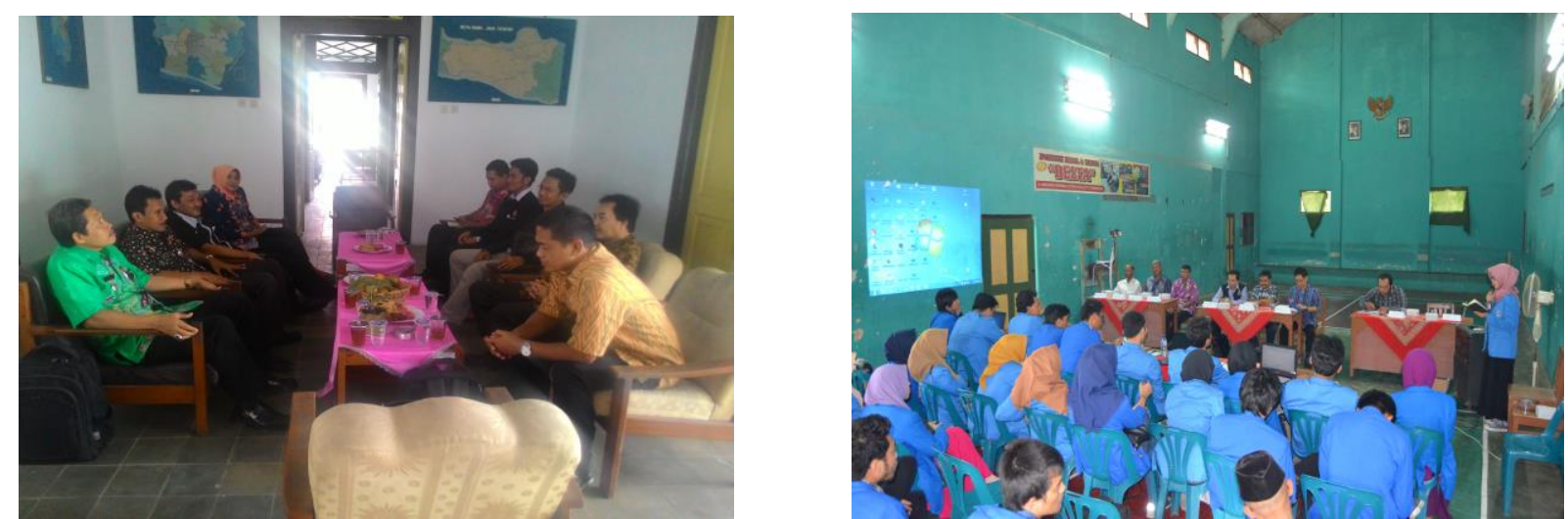

Gambar 5. Sosialisasi ke Masyarakat Penerima Hibah KKN-PPM

Pendampingan Peningkatan kapasitas

\section{Tata Kelola Pemerintahan Desa}

Kegiatan ini merupakan kegiatan KKN-PPM untuk memperkuat kelembagaan desa dalam menyongsong Undang-undang Desa Nomor 6 Tahun 2014. Sumber daya manusia pemerintahan desa yang berlatar belakang pendidikan SMPSMA menjadikan permasalahan terbaru dalam memahami Undang-undang Desa Nomor 6/2014. Kegiatan ini juga melakukan kegiatan pengarsipan adsministrasi desa yang selama ini belum tertata dengan baik.
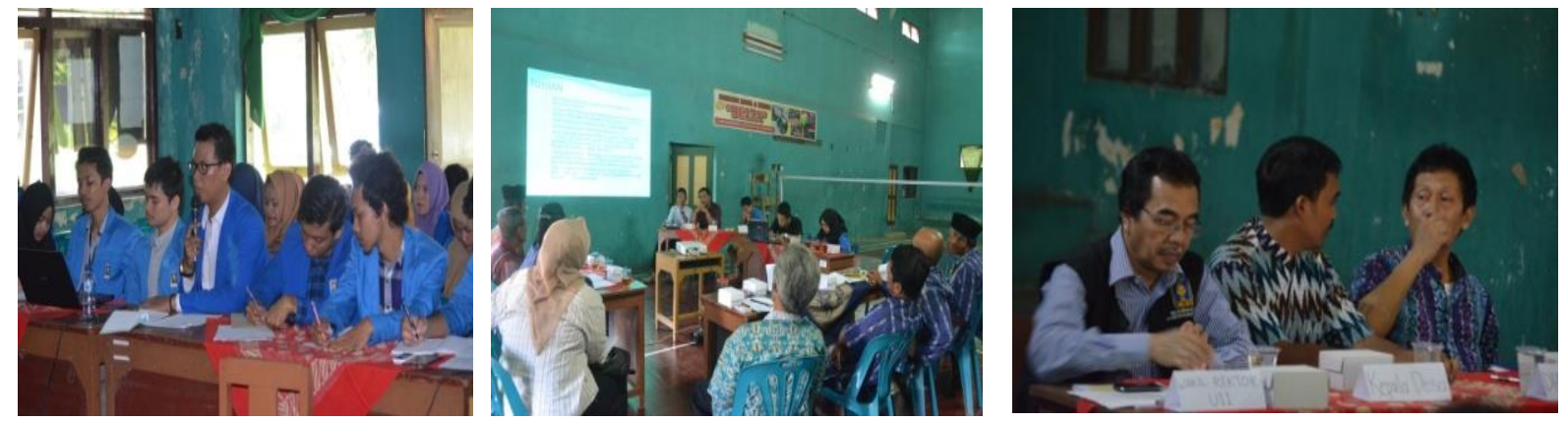

Gambar 6. Peningkatan Tata Kelola Pemerintahan Desa Perdes dan Legal Drafting
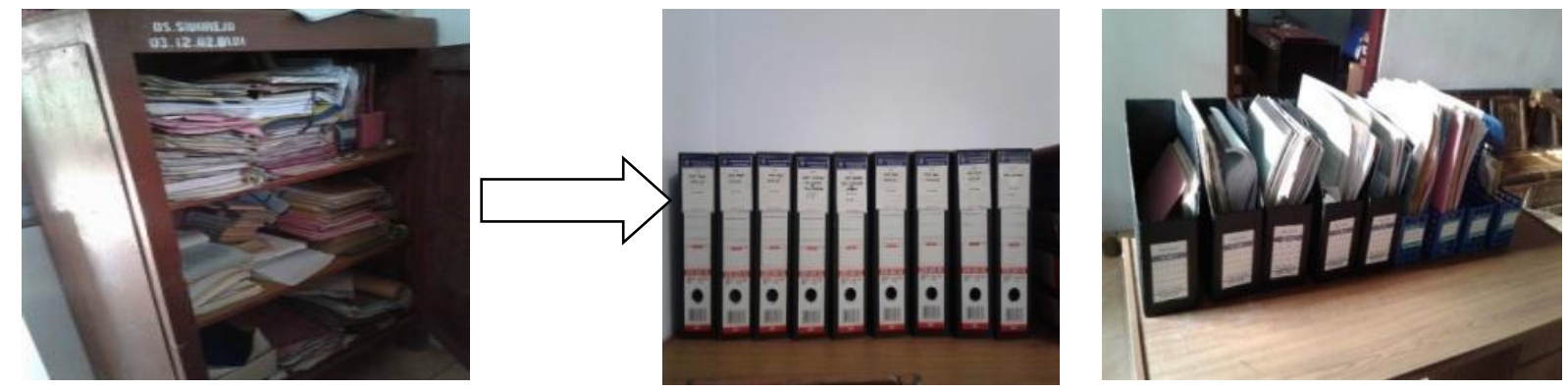

Gambar 7. Pengarsipan Adsministrasi Desa

Pendampingan Penyusunan Perencanaan Desa
Kegiatan ini merupakan kegiatan KKN -PPM dalam mendampingi lembaga 
desa dalam menyusun sebuah perencaaan desa berbasis potensi lokal. Perencaaan yang disusun bersifat parsial dan lebih cenderung pada insfrastuktur fisik dan
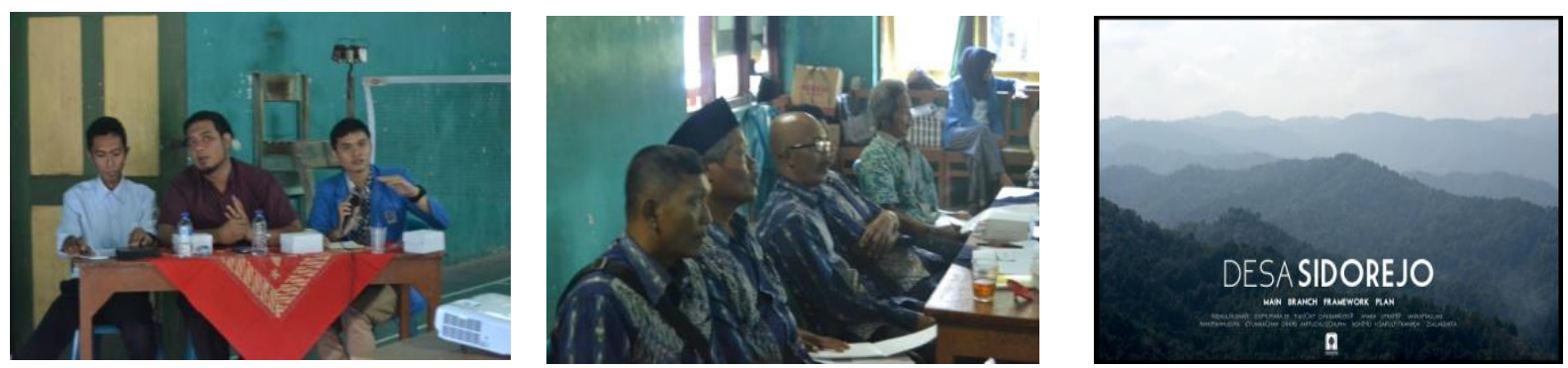

Gambar 8. Kegiatan Penyusunan Perencanaan Desa

Pendampingan Pemetaan Potensi dan Pendataan Ekonomi Desa

Kegiatan ini merupakan dalam rangka memetakan potensi ekonomi berbasis potensi lokal. Selama ini pemerintahan desa tidak memahami potensi yang di miliki sehingga program-program desa lebih tidak partisipatif dengan pelibtan aktif masyarakat dalam penyusunan rencana desa.
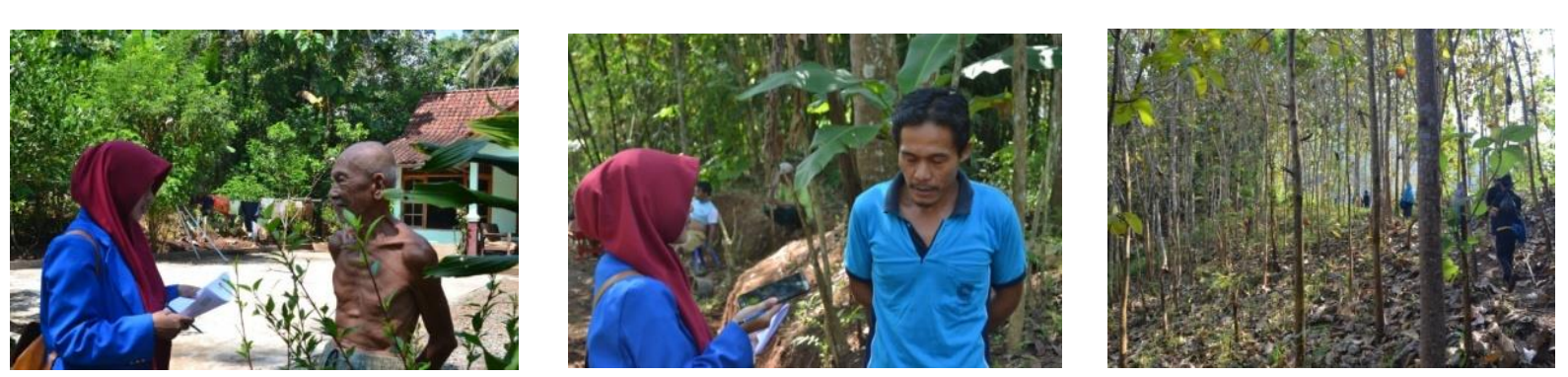

Gambar 9. Pemetaan potensi dan pendataan ekonomi desa

\section{Studi Banding Dalam Rangka Belajar Mengembangan Potensi Lokal}

Kegiatan ini merupakan kegiatan belajar langsung ke masyarakat di Dusun Ngijo, Desa Srimulyo, Piyungan, Bantul Daerah Istimewa Yogyakarta. Pemilihan lokasi tersebut dikarenakan Dusun Ngijo kepada program fisik. Dengan adanya pemetaan potensi ekonomi desa di harapkan desa dapat mengetahui dan mengembangkan potensi ekonomi yang dimiliki untuk meningkatkan kesejahteraan masyarakat dan kemajuan desa.

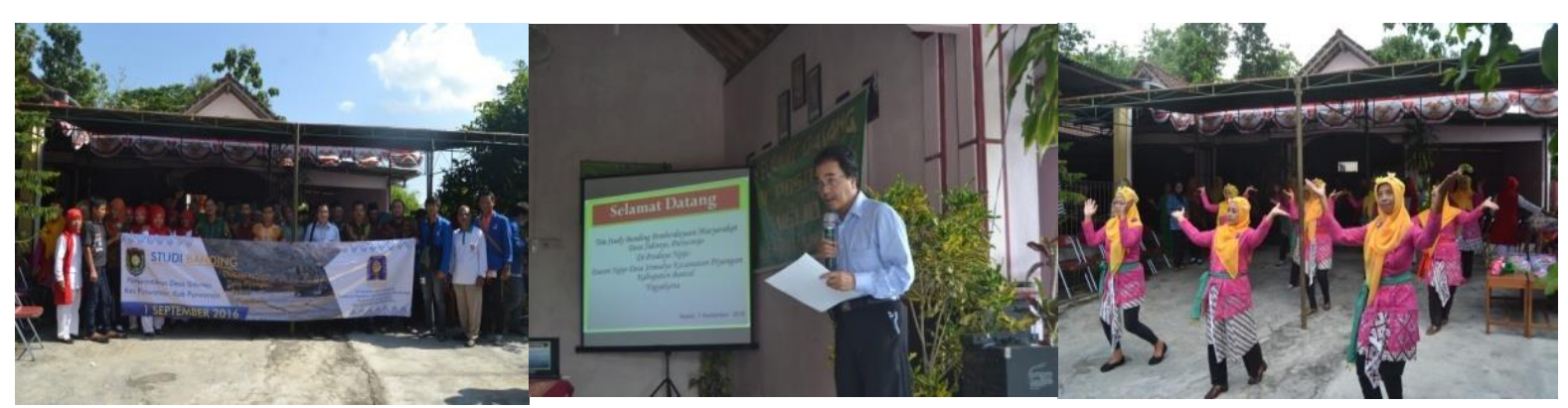

Gambar 10. Studi Banding Dalam Rangka Penguatan Kelembagaan Desa 
Pendampingan Ekonomi Kewirausahaan

Kegiatan ini merupakan kegiatan dalam rangka melakukan pengolahan

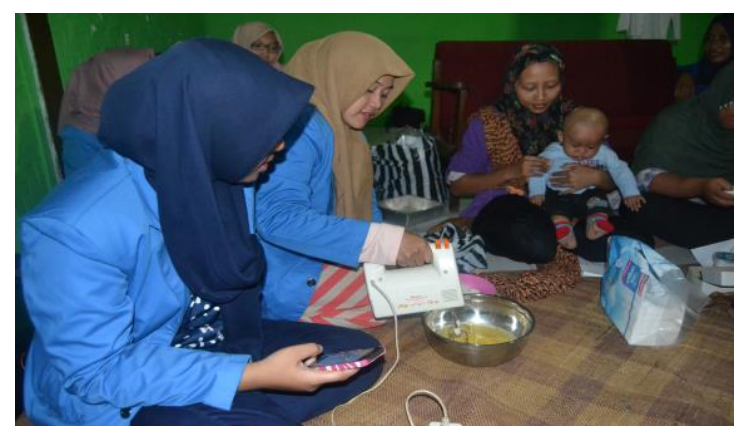

makanan dengan bahan baku lokal dengan tujuan agar tercipta diversifikasi produk dan bernilai ekonomis. Produk makanan yang diolah berbahan baku dari singkong.

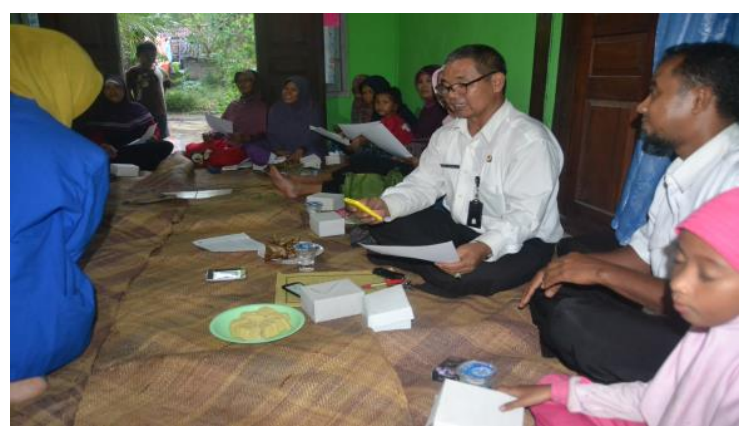

Gambar 12. Pendampingan Pengolahan Makanan dari Bahan Baku Lokal

\section{KESIMPULAN}

Dalam pelaksanaan laporan pengembangan potensi lokal melalui penguatan kelembagaan sebagai solusi pengentasan kemiskinan di Desa Sidorejo Kabupaten Purworejo dapat disimpulkan sebagai berikut:

1) Pelaksanaan KKN-PPM ini mendapatkan respon yang positif dari pemerintah desa, Pemerintah Kabupaten Purworejo dan masyarakat Desa Sidorejo

2) Hasil dari perencanaan, pendataan, dan pemetaan potensi ekonomi desa ini menjadi acuan dalam penyusunan perencanaan dan pengembangan desa Usulan dana desa.

3) Hasil dari pelaksanaan KKN-PPM ini menjadi program berkelanjutan KKN Universitas Islam Indonesia di Desa Sidorejo pada tahun 2017.

\section{SARAN}

Saran dalam pelaksanaan kegiatan Pengembangan potensi lokal melalui penguatan kelembagaan sebagai solusi pengentasan kemiskinan di Desa Sidorejo Kabupaten purworejo ini dapat ditindak lanjuti dengan kegiatan pendampingan ke masyarakat supaya hasil luaran yang dihasilkan dari kegiatan ini dapat terwujud dan bermanfaat untuk pengembangan desa.

\section{UCAPAN TERIMA KASIH}

Penulis mengucapkan terima kasih kepada Direktorat Riset dan Pengabdian Masyarakat (DRPM), Kementerian Riset, Teknologi dan Pendidikan Tinggi yang telah memberikan dana hibah untuk pelaksanaan kegiatan Pengabdian Masyarakat KKN-PPM (Kuliah Kerja Nyata-Program

Masyarakat) ini.

\section{DAFTAR PUSTAKA}

Sumaryadi, I Nyoman. 2005. Efektivitas Implementasi Kebijkan Otonomi Daerah. Jakarta: Penerbit Citra Utama

Yuwono, Teguh. 2001. Manajemen Otonomi Daerah :Membangun Daerah Berdasarkan Paradigma Baru. Semarang: Ciyapps Diponegoro Universiti

Hetifah, Sumarto, Sj. 2003. Inovasi, Partisipasidan Good Governance. Jakarta: Penerbit Yayasan Obor Indonesia 
Pattinama, M. J., (2009), Pengetasan Kemiskinan Dengan Kearifan Lokal (StudiKasus di Pulau Buru-Maluku dan Surade-Jawa Barat), Jurnal Makara Sosial Humaniora, 13 (1), 112.

Situmorang, J., (2007), Kaji Tindak Peningkatan Peran Koperasi dan UKM sebagai Lembaga Keuangan Alternatif, Jurnal Infokop, 2, 24-35.

Suharto, E., (2010), Membangun Masyarakat Memberdayakan Rakyat; Kajian Strategis Pembangunan Kesejahteraan Sosial \&Pekerjaan Sosial, Cet. ke-4, PT Refika Aditama: Bandung. 